\title{
Bacterial Biofilm Formation on Resorbing Magnesium Implants
}

\author{
Olga Charyeva ${ }^{1,2 *}$, Jessica Neilands ${ }^{3}$, Gunnel Svensäter ${ }^{3}$, Ann Wennerberg4 \\ ${ }^{1}$ aap Biomaterials GmbH, Dieburg, Germany \\ ${ }^{2}$ Laboratory for Experimental Trauma Surgery, Justus-Liebig University Giessen, Giessen, Germany \\ ${ }^{3}$ Department of Oral Biology, Faculty of Odontology, Malmö University, Malmö, Sweden \\ ${ }^{4}$ Department of Prosthodontics, Faculty of Odontology, Malmö University, Malmö, Sweden \\ Email: ${ }^{*}$ olga.charyeva@gmail.com
}

Received 20 January 2015; accepted 3 February 2015; published 6 February 2015

Copyright (C) 2015 by authors and Scientific Research Publishing Inc.

This work is licensed under the Creative Commons Attribution International License (CC BY).

http://creativecommons.org/licenses/by/4.0/

(c) $\underset{\mathrm{EY}}{\mathrm{B}}$ Open Access

\begin{abstract}
Background: Implant-associated infections are a result of bacterial adhesion to an implant surface and subsequent biofilm formation at the implantation site. This study compares different magnesium materials based on their ability to resist bacterial adhesion as well as further biofilm formation. Material and Methods: The surfaces of four magnesium-based materials (Mg2Ag, Mg10Gd, WE43 and $99.99 \%$ pure $\mathrm{Mg}$ ) were characterized using atomic force microscope. In addition, the samples were tested for their ability to resist biofilm formation. Planktonic bacteria of either $S$. epidermidis or $E$. faecalis were allowed to adhere to the magnesium surfaces for two hour followed by rinsing and, for $S$. epidermidis, further incubation of 24,72 and 168 h was carried out. Results: $E$. faecalis had a significantly stronger adhesion to all magnesium surfaces compared to $S$. epidermidis $(\mathrm{p}=0.001)$. Biofilm growth of $S$. epidermidis was different on various magnesium materials: the amount of bacteria increased up to $72 \mathrm{~h}$ but interestingly a significant decrease was seen at $168 \mathrm{~h}$ on Mg2Ag and WE43 surfaces. For pure Mg and Mg10Gd the biofilm formation reached plateau at $72 \mathrm{~h}$. Surface characteristics of resorbable magnesium materials were changing over time, and the surface was generally less rough at $168 \mathrm{~h}$ compared to earlier time points. No correlation was found between the surface topology and the amount of adherent bacteria. Conclusion: In early stages of biofilm adhesion, no differences between magnesium materials were observed. However, after $72 \mathrm{~h}$ Mg2Ag and WE43 had the best ability to suppress $S$. epidermidis' biofilm formation. Also, bacterial adhesion to magnesium materials was not dependent on samples' surface topology.
\end{abstract}

\section{Keywords}

Bacterial Biofilm, Magnesium, Surface Topology

\footnotetext{
${ }^{*}$ Corresponding author.
}

How to cite this paper: Charyeva, O., Neilands, J., Svensäter, G. and Wennerberg, A. (2015) Bacterial Biofilm Formation on Resorbing Magnesium Implants. Open Journal of Medical Microbiology, 5, 1-11. 


\section{Introduction}

Surgical site infection is one of the most commonly reported infection and accounts for $14 \%$ - $16 \%$ of all nosocomial infections among hospital patients [1] [2]. It is a major problem in orthopedics leading to implant failure and in severe cases may result in amputation and mortality [3]. Implant infections in dental and maxillofacial fields can lead to implant failure [4].

Implant-associated infections are the result of bacteria adhesion to an implant surface and subsequent biofilm formation at the implantation site [3]. Sources of infectious bacteria include the environment of the operating room, surgical equipment, clothing worn by medical and paramedical staff, resident bacteria on the patient's skin and bacteria already residing in the patient's body [3] [5]. Thus, secondary operations involving implant removal highly increases the risk of nosocomial infections.

Designing metallic implants that would resorb at the same rate as that of bone healing would minimize the risk of postoperative infections, decrease high costs associated with repeated surgeries, minimize recovery times, and thus promote higher quality of life to each individual patient. Magnesium has attracted much attention for its potential use in trauma and orthopedics fields due to its mechanical properties [6], biocompatibility [7], biodegradability and ability to stimulate new bone formation [8] [9]. It was shown that magnesium has higher antibacterial activity than titanium, and that this activity is further strengthened in presence of silver [10]. It is thus desirable to compare different magnesium alloys based on their bacteriostatic and bactericidal abilities.

It seems that bacterial adhesion to surface is highly dependent on surface roughness $\left(\mathrm{S}_{\mathrm{a}}\right)$ and developed surface area ratio $\left(\mathrm{S}_{\mathrm{dr}}\right)$ [4] [11]. The level of bacterial adherence to moderately rough titanium surfaces $\left(\mathrm{S}_{\mathrm{dr}} 58 \%\right)$ was five times greater than to smooth titanium surfaces $\left(\mathrm{S}_{\mathrm{dr}} 2.8 \%\right)$ [4]. Magnesium resorbs mainly by pitting corrosion [12] which results in surface changes and might promote bacterial adhesion. Thus, it is important to compare whether any correlation between biofilm adhesion and surface changes which occur during resorbtion exist. Parameters describing spatial properties, like $S_{\mathrm{d} s}$, as well as hybrid properties, like $S_{\mathrm{dr}}$, might further differentiate surfaces with similar $S_{a}$ characteristics [13].

Enterococci, specifically Enterococcus faecalis, is the third most common cause of nosocomial infection, and most infections in hospitalized patients are associated with the use of indwelling medical devices [14]. E. faecalis, a Gram-positive constituent of the human intestinal microbiome, has become a prominent pathogen of health care-associated infections over the past 3 decades [15]. Between 1980 and 2008, the frequency of nosocomial infections caused by Enterococcus faecium, the other frequently encountered enterococcal pathogen, increased by $8.8 \%$ [16]. E. faecalis and E. faecium infections together accounted for $16.0 \%$ of central line-associated bloodstream infections, $14.9 \%$ of catheter-associated urinary tract infections, and $11.2 \%$ of surgical site infections as reported by the United States National Healthcare Safety Network between 2006 and 2007 [17]. E. faecalis is also the primary causative agent of enterococcal endocarditis [18] [19] and is the most frequently isolated pathogen in secondary endodontic infections [20].

Staphylococcus epidermidis and Staphylococcus aureus represent, in absolute, the main causative agents of infection in orthopedics [21]. S. epidermidis is the most frequently isolated member of the group of coagulasenegative staphylococci from implant-associated infections and they are associated with nosocomial infections [3]. S. epiderimidis, a Gram-positive, non-spore forming facultative anaerobe that grows by aerobic respiration or fermentation, with diameters ranging from $0.5-1.5 \mathrm{~mm}$, belong to the normal microbiota of the human skin. They are characterized by individual cocci, which divide in more than one plane to form grape-like clusters [3].

The aim of this study was to compare magnesium materials on their ability to resist bacterial adhesion as well as further biofilm formation. The surface changes were measured in order to find the possible correlation between biovolume and surface characteristics.

\section{Materials and Methods}

\subsection{Sample Production}

The following materials were used to produce alloys for this study: magnesium (99.99\%, Xinxiang Jiuli Magnesium Co. Ltd., China), yttrium (99.95\%, Grirem Advanced Materials Co. Ltd., China), gadolinium (99.95\%, Grirem Advanced Materials Co., Ltd., China), rare earth mixture (Grirem Advanced Materials Co. Ltd., China), and silver (99.99\%, ESG Edelmetall-Handel GmbH \& Co. KG, Germany).

Three magnesium-based materials were produced: Mg2Ag (1.89\% Ag, the rest was Mg), Mg10Gd (8.4\% Gd, 
the rest was Mg), and WE43 (3.45\% Y, 2.03\% Nd, 0.84\% Ce, the rest was Mg). Pure magnesium (99.97\% Mg) was used as a control. The concentrations of magnesium Mg, Y, Nd and Ce were determined by spark emission spectrometer (Spectrolab M, Spektro, Germany) and the concentrations of Ag and Gd were determined by X-ray fluorescence spectrometer (Bruker AXS S4 Explorer, Bruker AXS GmbH., Germany). The materials were cast at HZG-MagIC.

The three magnesium alloys (Mg2Ag, Mg10Gd, WE43) were produced by permanent mould gravity casting. After melting the pure $\mathrm{Mg}$, the melt was held at $720^{\circ} \mathrm{C}$ and the preheated alloying elements were added with continuous stirring for 15 minutes. The melt was then poured into a preheated $\left(550^{\circ} \mathrm{C}\right)$ permanent steel mould treated with boron nitride. During the casting process cover gas was used $\left(\mathrm{SF}_{6}\right.$ and $\mathrm{Ar}$ mixture). The alloys were homogenized with a T4 heat treatment prior to extrusion in Ar atmosphere at $550^{\circ} \mathrm{C} \mathrm{(Mg10Gd} \mathrm{and} \mathrm{WE43)} \mathrm{and}$ at $420^{\circ} \mathrm{C}(\mathrm{Mg} 2 \mathrm{Ag})$ for $6 \mathrm{~h}$. Afterwards the alloys were extruded indirectly with an extrusion ratio of 4:25. The chamber of the extrusion machine was set to $370^{\circ} \mathrm{C}$ and the billets $(\mathrm{d}=30 \mathrm{~mm})$ were preheated for one hour at $370^{\circ} \mathrm{C} \mathrm{(Mg2Ag),} \mathrm{at} 390^{\circ} \mathrm{C}$ (WE43) and at $430^{\circ} \mathrm{C}$ (Mg10Gd). The extrusion speed was between 3 and $4.5 \mathrm{~mm} / \mathrm{sec}$. Pure Mg was casted by permanent mould direct chill casting. The cast billet $(\mathrm{d}=110 \mathrm{~mm})$ was extruded indirectly with an extrusion ratio of $1: 84$. The billet temperature was maintained at $340^{\circ} \mathrm{C}$ and the speed of the extrusion was $0.7 \mathrm{~mm} / \mathrm{sec}$. Discs (10 mm diameter and $1.5 \mathrm{~mm}$ thickness) were machined from the extruded bars.

\subsection{Sample Sterilization}

The samples were sonicated for 20 min in dry isopropanol, dried and gamma-sterilized at the BBF Sterilisationservice GmbH facility (Kernen, Germany) with a total dosage of 29 kGy.

\subsection{Bacterial Strains and Culture}

The strains used for biofilm assays were E. faecalis ATCC 29212 and S. epidermidis C121, isolated from the external side of peritoneal dialysis catheter [22]. All strains were routinely maintained on blood agar or in ToddHewitt broth (30 g. $\mathrm{l}^{-1}$; Difco Laboratories, Becton Dickinson \& Co, Sparks, MD) at $37^{\circ} \mathrm{C}$ in $5 \% \mathrm{CO}_{2}$.

\subsection{Biofilm Formation Assays}

The magnesium discs were pre-coated in human serum for $18 \mathrm{~h}$ and then washed twice in $2 \mathrm{ml}$ potassium phosphate buffer (PBS) for $10 \mathrm{~min}$ at $37^{\circ} \mathrm{C}$. Overnight broth cultures of S. epidermidis or E. faecalis was inoculated (1:10 dilution) into fresh, pre-warmed Todd-Hewitt broth and incubated at $37^{\circ} \mathrm{C}$ in $5 \% \mathrm{CO}_{2}$ to the mid-exponential growth phase (optical density at $600 \mathrm{~nm} \approx 0.6$ ). The bacterial suspension was centrifuged at $3000 \mathrm{rpm}$ for 10 min at $5^{\circ} \mathrm{C}$ washed once in PBS and re-suspended in $10 \%$ human serum to a final concentration of approximately $1 \times 10^{8}$ cells $\mathrm{ml}^{-1}$. The bacterial suspension was added to a microtiter plate with the magnesium discs and the bacteria were allowed to adhere for $2 \mathrm{~h}$ at $37^{\circ} \mathrm{C}$ on a rocking platform at 300 cycles per hour. Following incubation for $2 \mathrm{~h}$, the surfaces were rinsed twice in $2 \mathrm{ml}$ PBS with pH 7.5 to remove loosely bound cells. S. epidermidis was then further incubated for 24, 72 and $168 \mathrm{~h}$ respectively. Adhered cells were stained using the Live/Dead Bac Light staining kit (Molecular Probes) and then visualized using a fluorescent microscope (Aristoplan, Leitz). Ten images per surface were captured with a digital camera and the number of bacteria on each image was counted by hand in a field area of $15,600 \mathrm{\mu m}^{2}$. All experiments were carried out in triplicates for each surface.

\subsection{Surface Roughness Characterization}

Magnesium discs which were pre-coated in human serum for $18 \mathrm{~h}$ and then washed twice in $2 \mathrm{ml}$ potassium phosphate buffer (PBS) for $10 \mathrm{~min}$ at $37^{\circ} \mathrm{C}$. The micro titer plates with these magnesium discs in human serum but without bacteria were incubated at $37^{\circ} \mathrm{C}$ on a rotary shaker at 300 cycles per hour in $5 \% \mathrm{CO}_{2}$ for $2,24,72$ and $168 \mathrm{~h}$. The human serum was changed every second day. At different time points the discs were removed and allowed to dry at room temperature. Surface characterization was performed by atomic force microscope, AFM (XE-100, Park Systems Corp, Suwon, Korea). Measurement areas of $10 \times 10 \mu \mathrm{m}$ in three random positions were selected for each disc. The measurements were performed at a scan rate of $0.50 \mathrm{~Hz}$. The images acquired from AFM were subjected to leveling and Gaussian filtering with a cut-off of $2.5 \mu \mathrm{m}$ was applied using the software MontainsMap ${ }^{\circledR}$ Universal 6.2 (Digital Surf, Besancon, France) and 3-D parameters such as $S_{a}$, $S_{d r}$, 
$\mathrm{S}_{\mathrm{ds}}$ were analyzed.

\subsection{Statistical Analysis}

Data were analyzed using the Statistical Package for the Social Sciences (SPSS, v18, SPSS Inc, Chicago, USA). The significance level was set at $5 \%$. Standard analyses comparing different groups were conducted via one-way repeated measures analysis of variance (ANOVA). One-way repeated measures ANOVA was performed with the Dunn or Holm-Sidak post-hoc test. Since the data was non-normally distributed, Kruskal-Wallis test was performed to compare parameters between the groups. All graphs were plotted using SPSS.

\section{Results}

\subsection{Adhesion of S, epidermidis and E. faecalis to Magnesium Surfaces}

E. faecalis had significantly stronger adhesion than $S$. epidermidis with respect to the same samples $(\mathrm{p}=0.001)$. Comparison between adhesion of $S$. epidermidis and E. faecalis to magnesium materials after $2 \mathrm{~h}$ of incubation is presented in Figure 1. This was true for all tested materials. The viability of the adhered cells of both $E$. faecalis and S. epidermidis was high (>95\% for both strains) and not statistically different from each other. No significant differences were found between materials within the same bacterial adhesion assay. In genereal, all magnesium samples were densely covered with $E$. faecalis, whereas $S$. epidermidis colonies were scarcely spread over the surface. Figure 2 shows this trend for Mg2Ag.
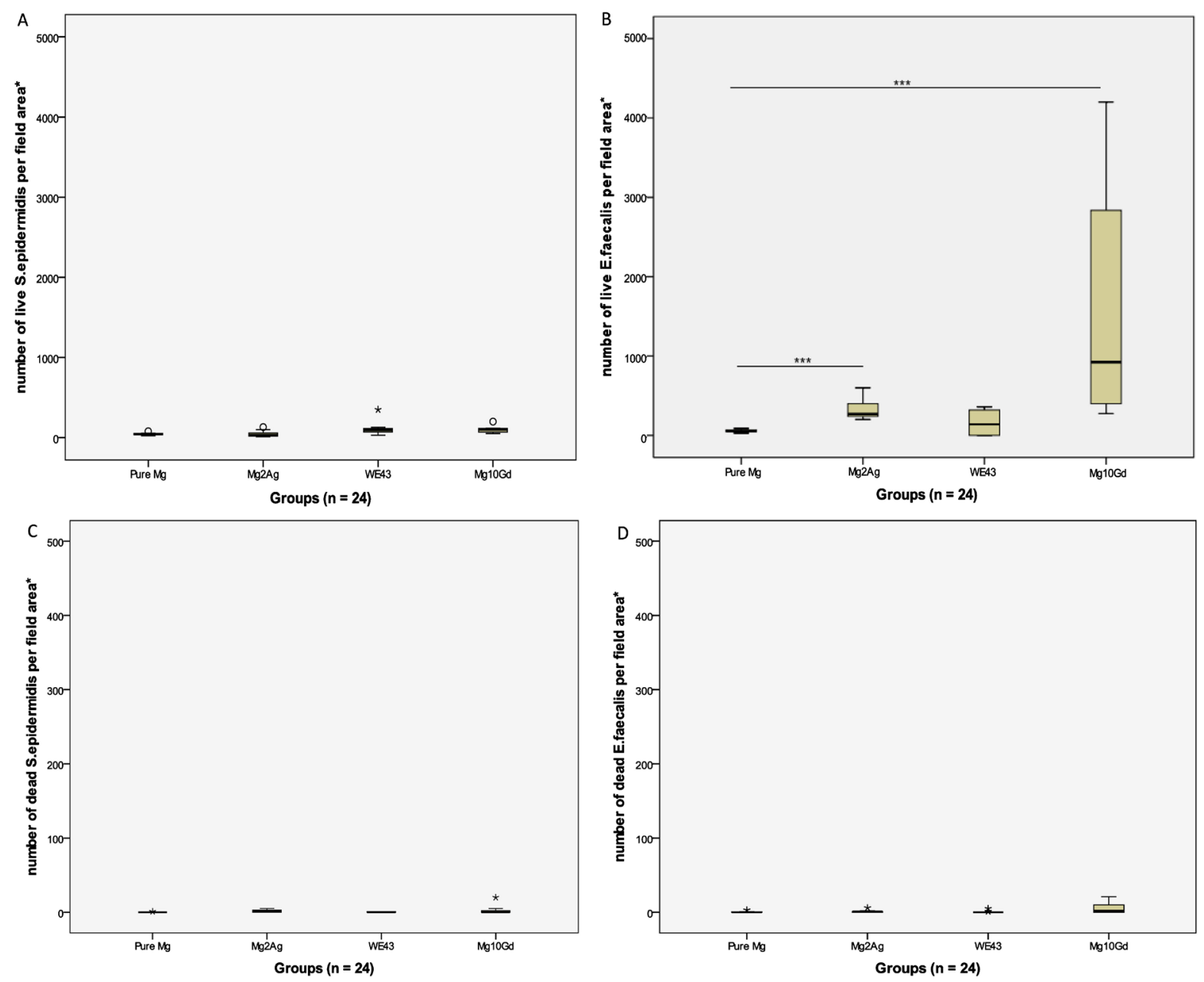

Figure 1. Adhesion of S. epidermidis and E. faecalis to magnesium materials after 2 h of incubation. (A) Live S. epidermidis; (B) Live E. faecalis; (C) Dead S. epidermidis; (D) Dead E. faecalis. *Field area represents 15,600 $\mu^{2}$. 


\subsection{S. epidermidis Growth over Time}

Biofilm growth of $S$. epidermidis on magnesium materials over time is presented in Figure 3(a). In general, Mg2Ag and WE43 had similar pattern of the biofilm growth, whereas pure Mg was comparable to Mg10Gd. The number of adherent bacteria increased up to $72 \mathrm{~h}$ of incubation for all tested samples. Between $72 \mathrm{~h}$ and 168 $\mathrm{h}$, the biofilm reached its plateau for pure Mg and Mg10Gd. Whereas, for Mg2Ag and WE43, the amount of adhered S. epidermidis decreased between 72 and $168 \mathrm{~h}$.

The viability of the cells remained high (>95\%) at all time-points as shown by the low number of dead cells. There was no significant difference between the groups in the amount of dead S. epidermidis at the different time points. Even inside the group, no statistically significant differences were observed (Figure 3(b)). The pattern of S. epidermidis growth on pure Mg over time is shown in Figure 4.

\subsection{Characterisation of Surface Roughness}

Surface topology was quantified starting from $0 \mathrm{~h}$ when bacteria were seeded onto the samples. It was observed that $S_{a}$ values for pure Mg significantly increased from 0 to $2 \mathrm{~h}$, and then slightly decreased at $168 \mathrm{~h}$ (Figure 5). The surface of Mg2Ag stayed stable over time with no significant changes in $\mathrm{S}_{\mathrm{a}}$. WE43 was comparable to Mg2Ag but with a significant $S_{a}$ decrease between 24 and $168 \mathrm{~h}$. Significant decrease in $\mathrm{S}_{\mathrm{a}}$ was observed for Mg10Gd at 0 and $168 \mathrm{~h}$.
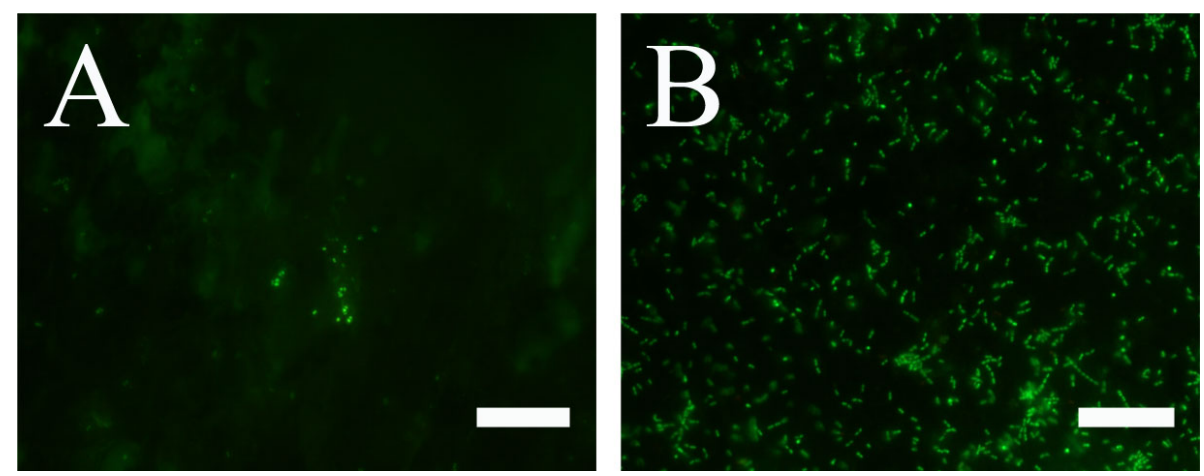

Figure 2. (A) S. epidermidis on Mg2Ag's surface at 2 h; (B) E. faecalis on Mg2Ag's surface at 2 h. Scale bar represents 30 $\mu \mathrm{m}$.
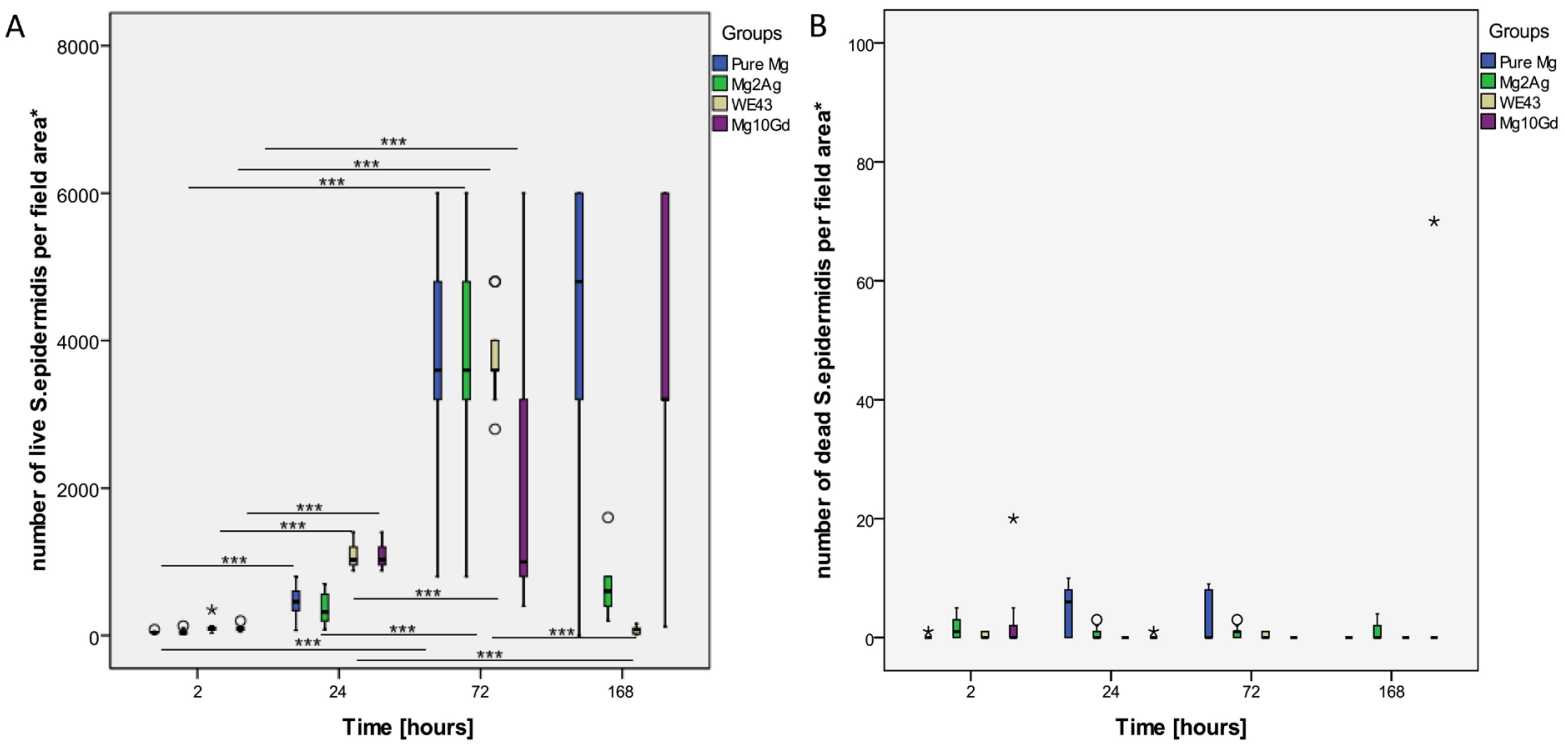

Figure 3. (A) Adherence of live S. epidermidis to magnesium surfaces over time; (B) Adherence of dead S. epidermidis to magnesium surfaces over time. *Field area represents $15,600 \mu^{2}$. 

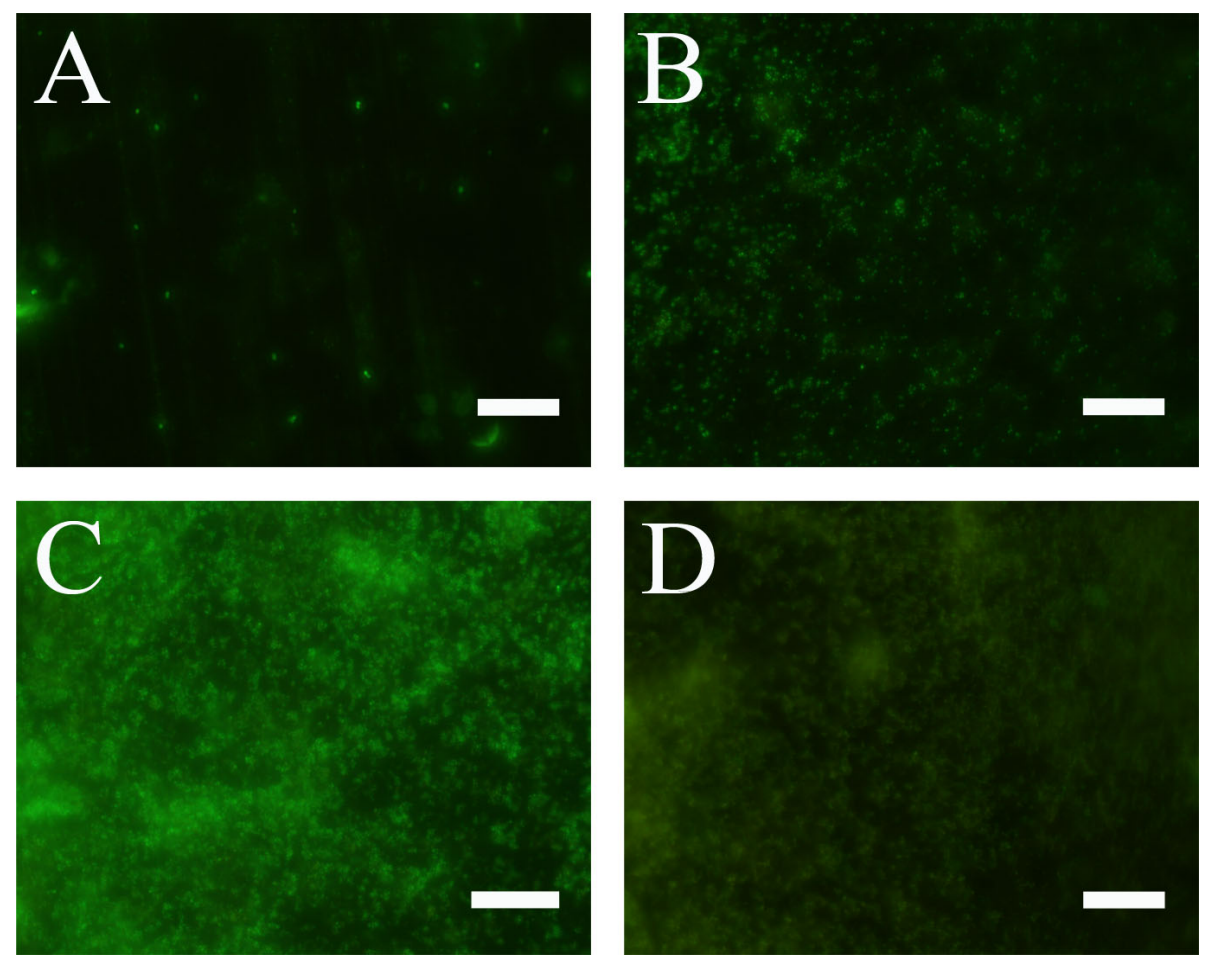

Figure 4. Adherence of S. epidermidis to pure Mg at (A) 2 h; (B) 24 h; (C) 72 h; (D) 168 h. Scale bar represents $30 \mu \mathrm{m}$.

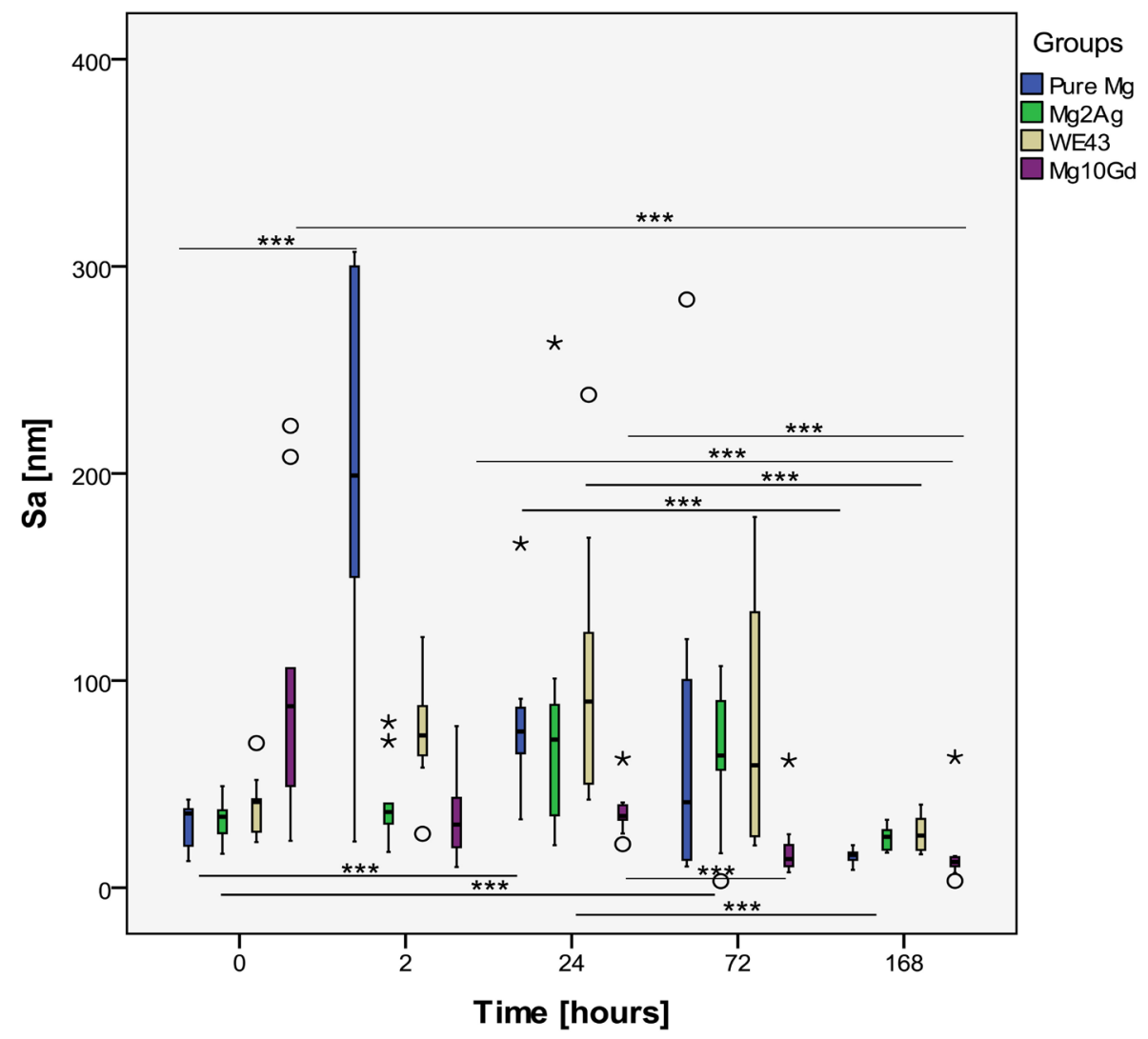

Figure 5. $\mathrm{S}_{\mathrm{a}}$, average surface roughness, of magnesium alloys over time. 
The pattern of $S_{d r}$ change over time was very similar to $S_{a}$ and is presented in Figure 6 . $S_{d s}$ behavior was similar for all tested materials (Figure 7). In general, $S_{d s}$ decreased from $0 \mathrm{~h}$ to $2 \mathrm{~h}$ but then stayed quite stable over time. No correlation between the surface topology and amount of adherent bacteria were found in this study.

\section{Discussion}

Implant-associated infections are the result of bacteria adhesion to an implant surface and subsequent biofilm formation at the implantation site. This study compared magnesium materials on their ability to resist bacterial adhesion as well as further biofilm formation. The surface changes were measured in order to find the possible correlation between biovolume and surface characteristics.

Adhesion of E. faecalis was significantly better than adhesion of $S$. epidermidis to the same samples. This means that different bacterial strains have different ability to bind to magnesium surfaces under the same conditions which can be supported by previous studies on microbiology [23]. In this study, no correlation was found between the surface topology and the ability of the bacteria to adhere to the magnesium surface, although this correlation was observed in previous research [4]. Resorbtion of magnesium is a very complex chemical process. Surface topology is one of many factors that might influence cell and bacteria adherence and there are many more aspects that should be taken into account when analyzing magnesium's performance in vitro.

It has been shown in previous studies that magnesium changes the surrounding environment; it makes $\mathrm{pH}$ more basic [24] [25] which in turn stimulates precipitation of $\mathrm{Ca}^{2+}$ ions from the solution [24]-[26] thereby changing the osmolality [26] and thus reacts with the medium to form $\mathrm{H}_{2}$ gas [27]. The surrounding environment also has an effect on magnesium since it promotes formation of the protective layer on its surface [27]. Protective layer slows down further degradation but is brittle and cleaves off from the surface quite easily [28]. This means that the surface topology of magnesium materials is constantly changing. In this study, it was observed that in the first hours $S_{a}$ increased which can be explained by removal of surface irregularities and particles that are present on the surface. Later, the summits start to resorb and their tops break off from the surface

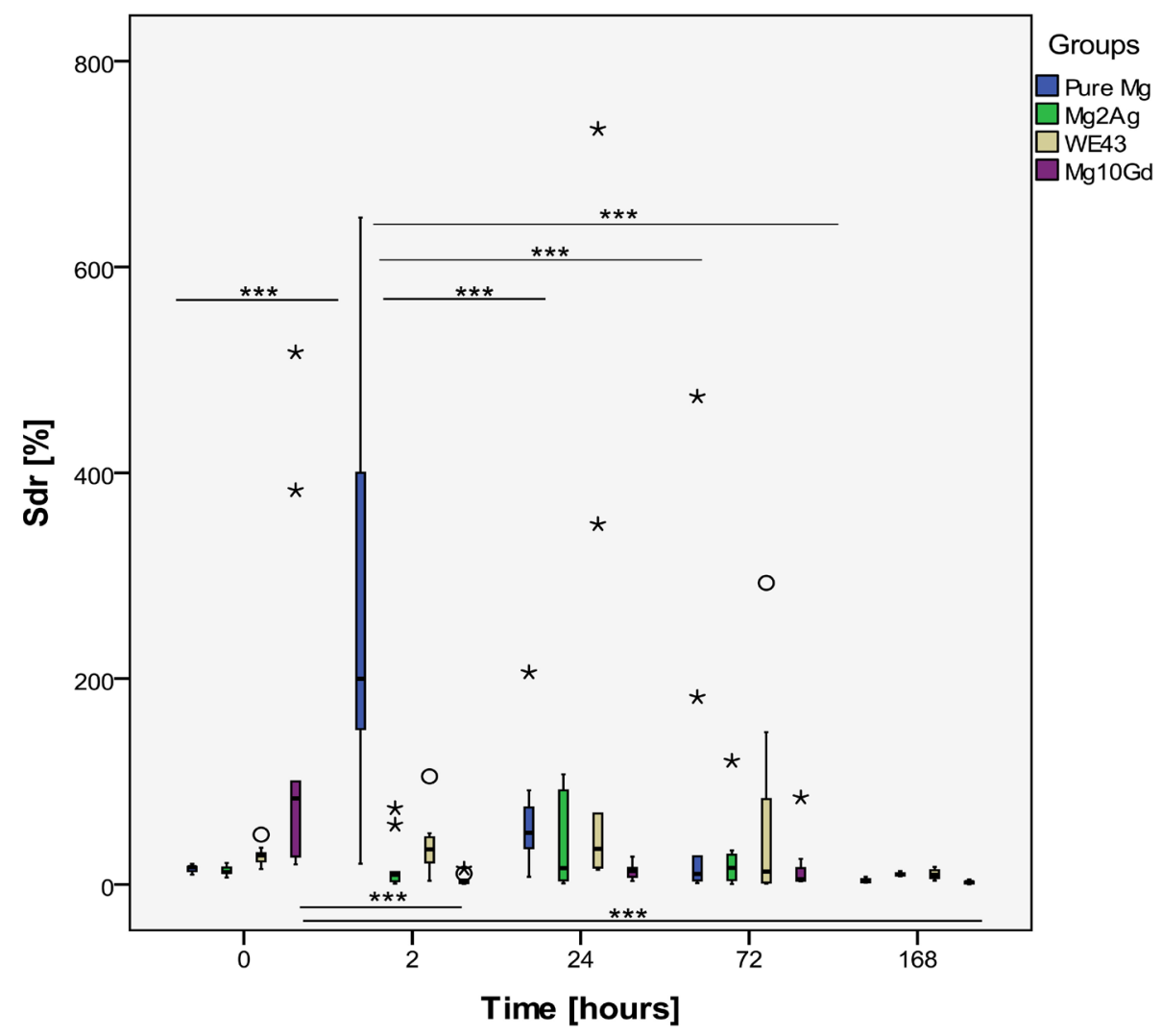

Figure 6. $\mathrm{S}_{\mathrm{dr}}$, a ratio between the 3-D measurement and a 2-D reference plane, of magnesium alloys over time. 


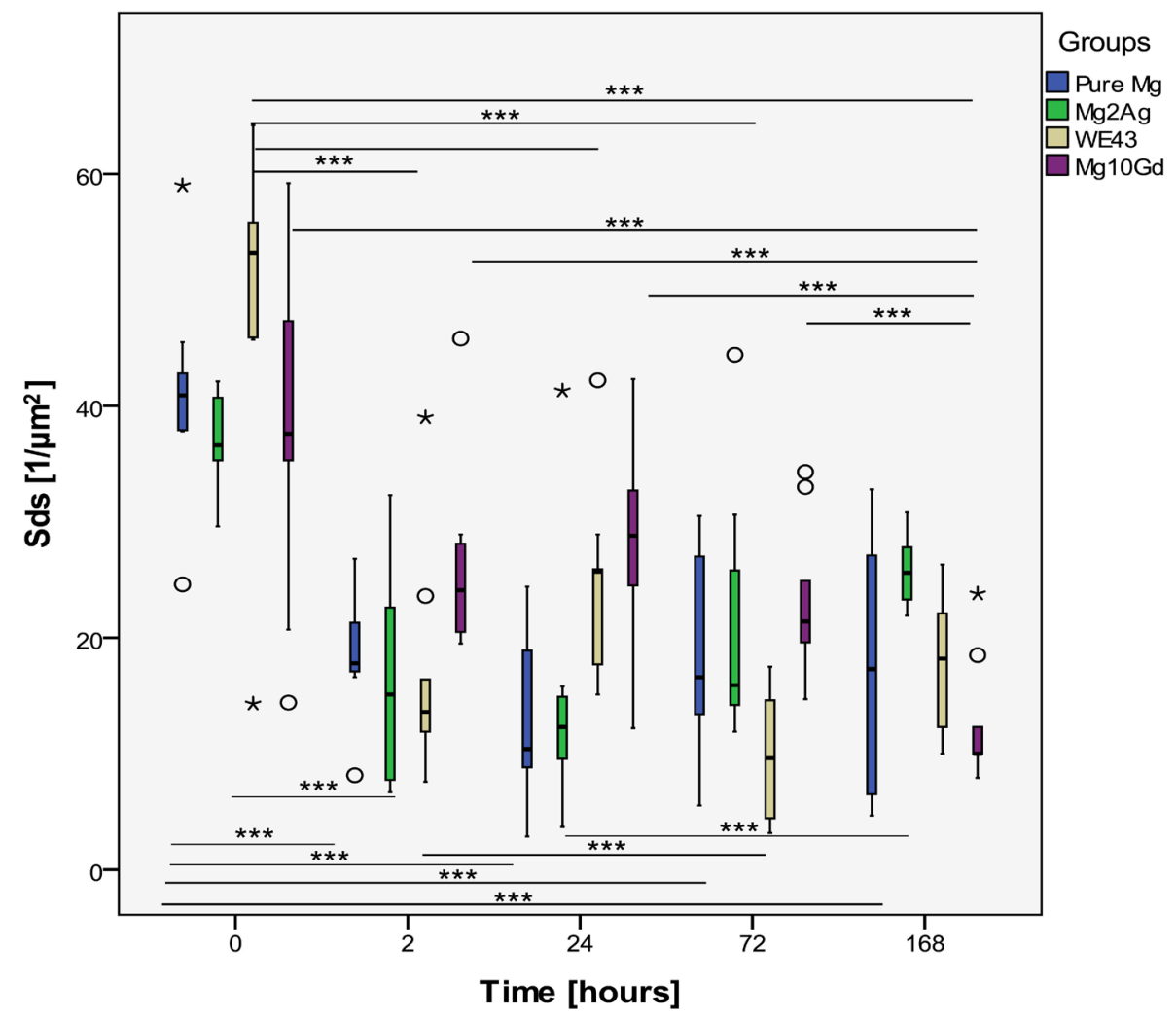

Figure $7 . \mathrm{S}_{\mathrm{ds}}$, the number of summits per unit area making up the surface, of magnesium alloys over time.

decreasing the $\mathrm{S}_{\mathrm{ds}}$. At later stages, the protective layer consisting of calcium phosphates and precipitated proteins from the medium is formed on the surface decreasing $S_{a}$ and $S_{d r}$ values.

Bacterial adhesion to magnesium surfaces is lower compared to titanium surfaces [10]. Antibacterial properties of magnesium might be explained by the changes that magnesium promotes in its surroundings. As stated previously, magnesium makes $\mathrm{pH}$ basic through the release of $\mathrm{OH}^{-}$ions in contact with fluids [24] [25] [27]. The higher $\mathrm{pH}$ inhibits enzyme activities that are essential to bacterial life, i.e. metabolism, growth, and cellular division [29].

It was shown in previous studies that $S$. epidermidis grows best in slightly more acidic $\mathrm{pH}$ close to around 6.35 but demonstrates the ability to growth in a range of $\mathrm{pHs}$ [30] [31]. In this study S. epidermidis seemed to be resistant to alkali $\mathrm{pH}$ due to the effects of magnesium, as revealed by the increase in the bacterial number up to $72 \mathrm{~h}$ for all samples tested. After $72 \mathrm{~h} \mathrm{Mg2Ag}$ and WE43 suppressed further bacterial growth on their surfaces. This might be due to the release of $\mathrm{Ag}^{2+}$ ions which are known for their antibacterial properties [10]. In case of WE43, the decreased number of adherent bacteria after $72 \mathrm{~h}$ might be due to high resorbtion rate of this alloy [32] and consequent formation of $\mathrm{H}_{2}$ gas which acts as a physical barrier for further biofilm growth. Pure $\mathrm{Mg}$ and Mg10Gd both had bacteriostatic effect after $72 \mathrm{~h}$ which might be either due to the change in the surrounding environment which became less favorable for $S$. epidermidis, or due to the high biovolume which suppresses further biofilm growth.

It was shown in previous studies that unlike S. epidermidis, E. faecalis can survive in highly alkaline $\mathrm{pH}$, and some clinical isolates require $72 \mathrm{~h}$ at $\mathrm{pH} 12.5$ to be killed [33]. Mild alkaline mediums (pH 7 - 9) had no effect on $E$. faecalis vitality and high alkaline condition $(\mathrm{pH}>10)$ led to a significant decline in the survival rate of bacteria in one study [34]. Also the biofilm cells of E. faecalis were more alkaline tolerant than corresponding planktonic cells [34]. This can explain why there were more $E$. faecalis adhered to magnesium samples compared to $S$. epidermidis which are less resistant to alkali $\mathrm{pH}$. Based on the previous research results it can be hypothesised that $E$. faecalis would have continued its biofilm growth if the experimental time would have been prolonged. 
Dead E. faecalis and S. epidermidis were few in this study. The surface was predominantly occupied by live bacteria. Thus, magnesium seems to have no bactericidal effect. With time no increase in dead S. epidermidis was observed, their number was stable over the observation period.

Magnesium alloys seemed to suppress the adhesion of $S$. epidermidis in the first hours of experiment. Unlike S. epidermidis, E. faecalis binded to magnesium more readily at $2 \mathrm{~h}$. One of the limitations of this study is that it does not compare magnesium to titanium surfaces and it is thus not possible to see whether magnesium is better in its ability to prevent biofilm adhesion than titanium. Resorption of magnesium alloys is a complex process which involves alterations of material's surface and changes in the surrounding environment. Thus the task of the future research in this area would be determination of factors that suppresses bacterial vitality.

\section{Conclusion}

Various bacterial strains had different adherence capacity to magnesium-based materials. There were no differences between different magnesium materials based on their ability to withstand biofilm formation at early stages up to $72 \mathrm{~h}$. However, after $72 \mathrm{~h} \mathrm{Mg2Ag}$ and WE43 had more favorable properties than pure Mg and Mg10Gd in their ability to suppress bacterial growth. These changes in biofilm growth and adherence could not be attributed to the changes in surface topology.

\section{Acknowledgements}

This project receives funding from the People Programme (Marie Curie Actions) of the European Union's Seventh Framework Programme FP7 (2007-2013) under REA Grant Agreement No 289163.

\section{Conflict of Interest Statement}

The authors declare that they have no conflict of interest.

\section{References}

[1] Smyth, E.T. and Emmerson, A.M. (2000) Surgical Site Infection Surveillance. Journal of Hospital Infection, 45, 173184. http://dx.doi.org/10.1053/jhin.2000.0736

[2] Smyth, E.T., McIlvenny, G., Enstone, J.E., Emmerson, A.M., Humphreys, H., Fitzpatrick, F., Davies, E., Newcombe, R.G. and Spencer, R.C. (2008) Four Country Healthcare Associated Infection Prevalence Survey 2006: Overview of the Results. Journal of Hospital Infection, 69, 230-248. http://dx.doi.org/10.1053/jhin.2000.0736

[3] Ribeiro, M., Monteiro, F.J. and Ferraz, M.P. (2012) Infection of Orthopedic Implants with Emphasis on Bacterial Adhesion Process and Techniques Used in Studying Bacterial-Material Interactions. Biomatter, 2, 176-194. http://dx.doi.org/10.4161/biom.22905

[4] Dorkhan, M., Chávez de Paz, L.E., Skepö, M., Svensäter, G. and Davies, J.R. (2012) Effects of Saliva or Serum Coating on Adherence of Streptococcus oralis Strains to Titanium. Microbiology, 158, 390-397. http://dx.doi.org/10.1099/mic.0.054536-0

[5] Frank, K.L., Guiton, P.S., Barnes, A.M., Manias, D.A., Chuang-Smith, O.N., Kohler, P.L., Spaulding, A.R., Hultgren, S.J., Schlievert, P.M. and Dunny, G.M. (2013) AhrC and Eep Are Biofilm Infection-Associated Virulence Factors in Enterococcus faecalis. Infection and Immunity, 81, 1696-1708. http://dx.doi.org/10.1128/IAI.01210-12

[6] Xin, Y., Hu, T. and Chu, P.K. (2011) In Vitro Studies of Biomedical Magnesium Alloys in a Simulated Physiological Environment: A Review. Acta Biomater, 7, 1452-1459. http://dx.doi.org/10.1016/j.actbio.2010.12.004

[7] Gu, X., Zheng, Y., Cheng, Y., Zhong, S. and Xi, T. (2009) In Vitro Corrosion and Biocompatibility of Binary Magnesium Alloys. Biomaterials, 30, 484-498. http://dx.doi.org/10.1016/j.biomaterials.2008.10.021

[8] Xu, L., Yu, G., Zhang, E., Pan, F. and Yang, K. (2007) In Vivo Corrosion Behavior of Mg-Mn-Zn Alloy for Bone Implant Application. Journal of Biomedical Materials Research Part A, 83, 703-711. http://dx.doi.org/10.1002/jbm.a.31273

[9] Witte, F., Kaese, V., Haferkamp, H., Switzer, E., Meyer-Lindenberg, A., Wirth, C.J. and Windhagen, H. (2005) In Vivo Corrosion of Four Magnesium Alloys and the Associated Bone Response. Biomaterials, 26, 3557-3563. http://dx.doi.org/10.1016/j.biomaterials.2004.09.049

[10] Tie, D., Feyerabend, F., Müller, W.D., Schade, R., Liefeith, K., Kainer, K.U. and Willumeit, R. (2013) Antibacterial Biodegradable Mg-Ag alloys. European Cells and Materials Journal, 25, 284-298.

[11] Bürgers, R., Gerlach, T., Hahnel, S., Schwarz, F., Handel, G. and Gosau, M. (2010) In Vivo and in Vitro Biofilm For- 
mation on Two Different Titanium Implant Surfaces. Clinical Oral Implants Research, 21, 156-164. http://dx.doi.org/10.1111/j.1600-0501.2009.01815.x

[12] Witte, F., Kaese, V., Haferkamp, H., Switzer, E., Meyer-Lindenberg, A., Wirth, C.J. and Windhagen, H. (2005) In Vivo Corrosion of Four Magnesium Alloys and the Associated Bone Response. Biomaterials, 26, 3557-3563. http://dx.doi.org/10.1016/j.biomaterials.2004.09.049

[13] Stout, K.J., Sullivan, P.J., Dong, W.P., Mainsah, E., Luo, N., Mathia, T. and Zahouani, H. (1993) Development of Methods for Characterisation of Roughness in Three Dimensions. European Community Contract No 3374/1/0/170/90/2, University of Birmingham, Birmingham.

[14] Paganelli, F.L., Willems, R.J., Jansen, P., Hendrickx, A., Zhang, X., Bonten, M.J. and Leavis, H.L. (2013) Enterococcus faecium Biofilm Formation: Identification of Major Autolysin AtlA $\mathrm{Efm}_{\mathrm{fm}}$, Associated Acm Surface Localization, and Atl $_{\mathrm{Efm}}$-Independent Extracellular DNA Release. mBio, 4, e00154-13. http://dx.doi.org/10.1128/mBio.00154-13

[15] Frank, K.L., Guiton, P.S., Barnes, A.M., Manias, D.A., Chuang-Smith, O.N., Kohler, P.L., Spaulding, A.R., Hultgren, S.J., Schlievert, P.M. and Dunny, G.M. (2013) AhrC and Eep Are Biofilm Infection-Associated Virulence Factors in Enterococcus faecalis. Infection and Immunity, 81, 1696-1708. http://dx.doi.org/10.1128/IAI.01210-12

[16] Kang, J., Sickbert-Bennett, E.E., Brown, V.M., Weber, D.J. and Rutala, W.A. (2012) Relative Frequency of Health Care-Associated Pathogens by Infection Site at a University Hospital from 1980 to 2008. American Journal of Infection Control, 40, 416-420. http://dx.doi.org/10.1016/j.ajic.2011.06.013

[17] Hidron, A.I., Edwards, J.R., Patel, J., Horan, T.C., Sievert, D.M., Pollock, D.A. and Fridkin, S.K., for the National Healthcare Safety Network Team and Participating National Healthcare Safety Network Facilities (2008) NHSN Annual Update: Antimicrobial-Resistant Pathogens Associated with Healthcare-Associated Infections: Annual Summary of Data Reported to the National Healthcare Safety Network at the Centers for Disease Control and Prevention, 2006-2007. Infection Control and Hospital Epidemiology, 29, 996-1011. http://dx.doi.org/10.1086/591861

[18] McDonald, J.R., Olaison, L., Anderson, D.J., Hoen, B., Miro, J.M., Eykyn, S., Abrutyn, E., Fowler Jr., V.G., Habib, G., Selton-Suty, C., Pappas, P.A., Cabell, C.H., Corey, G.R., Marco, F. and Sexton, D.J. (2005) Enterococcal Endocarditis: 107 Cases from the International Collaboration on Endocarditis Merged Database. American Journal of Medicine, 118, 759-766. http://dx.doi.org/10.1016/j.amjmed.2005.02.020

[19] Fernández Guerrero, M.L., Goyenechea, A., Verdejo, C., Roblas, R.F. and de Górgolas, M. (2007) Enterococcal Endocarditis on Native and Prosthetic Valves: A Review of Clinical and Prognostic Factors with Emphasis on Hospital-Acquired Infections as a Major Determinant of Outcome. Medicine, 86, 363-377. http://dx.doi.org/10.1097/MD.0b013e31815d5386

[20] Tennert, C., Fuhrmann, M., Wittmer, A., Karygianni, L., Altenburger, M.J., Pelz, K., Hellwig, E. and Al-Ahmad, A. (2014) New Bacterial Composition in Primary and Persistent/Secondary Endodontic Infections with Respect to Clinical and Radiographic Findings. Journal of Endodontics, 40, 670-677. http://dx.doi.org/10.1016/j.joen.2013.10.005

[21] Campoccia, D., Montanaro, L. and Arciola, C.R. (2006) The Significance of Infection Related to Orthopedic Devices and Issues of Antibiotic Resistance. Biomaterials, 27, 2331-2339. http://dx.doi.org/10.1016/j.biomaterials.2005.11.044

[22] Pihl, M., Chávez de Paz, L.E., Schmidtchen, A., Svensäter, G. and Davies, J.R. (2010) Effects of Clinical Isolates of Pseudomonas aeruginosa on Staphylococcus epidermidis Biofilm Formation. FEMS Immunology and Medical Microbiology, 59, 504-512.

[23] Guo, L., He, X. and Shi, W. (2014) Intercellular Communications in Multispecies Oral Microbial Communities. Frontiers in Microbiology, 5, 328.

[24] Witte, F., Hort, N., Vogt, C., Cohen, S., Kainer, K.U., Willumeit, R. and Feyerabend, F. (2008) Degradable Biomaterials Based on Magnesium Corrosion. Current Opinion in Solid State and Materials Science, 12, 63-72. http://dx.doi.org/10.1016/j.cossms.2009.04.001

[25] Willumeit, R., Fischer, J., Feyerabend, F., Hort, N., Bismayer, U., Heidrich, S. and Mihailova, B. (2011) Chemical Surface Alteration of Biodegradable Magnesium Exposed to Corrosion Media. Acta Biomaterialia, 7, 2704-2715. http://dx.doi.org/10.1016/j.actbio.2011.03.004

[26] Feyerabend, F., Drücker, H., Laipple, D., Vogt, C., Stekker, M., Hort, N. and Willumeit, R. (2012) Ion Release from Magnesium Materials in Physiological Solutions under Different Oxygen Tensions. Journal of Materials Science: Materials in Medicine, 23, 9-24. http://dx.doi.org/10.1007/s10856-011-4490-5

[27] Staiger, M.P., Pietak, A.M., Huadmai, J. and Dias, G. (2006) Magnesium and Its Alloys as Orthopedic Biomaterials: A Review. Biomaterials, 27, 1728-1734. http://dx.doi.org/10.1016/j.biomaterials.2005.10.003

[28] Hornberger, H., Virtanen, S. and Boccaccini, A.R. (2012) Biomedical Coatings on Magnesium Alloys: A Review. Acta Biomaterialia, 8, 2442-2455. http://dx.doi.org/10.1016/j.actbio.2012.04.012

[29] Prabhakar, A.R., Savita Hadakar, G. and Raju, O.S. (2012) Comparative Evaluation of pH and Antibacterial Effect of Various Calcium Hydroxide Combinations on E. faecalis and Its Effect on Root Strength: An in Vitro Study. Con- 
temporary Clinical Dentistry, 3, 42-47. http://dx.doi.org/10.4103/0976-237X.94545

[30] McDonald, W.A., Watts, J. and Bowmer, M.I. (1986) Factors Affecting Staphylococcus epidermidis Growth in Peritoneal Dialysis Solutions. Journal of Clinical Microbiology, 24, 104-107.

[31] Korting, H.C., Lukacs, A., Vogt, N., Urban, J., Ehret, W., Ruckdeschel, G., Korting, H.C., Lukacs, A., Vogt, N., Urban, J., Ehret, W. and Ruckdeschel, G. (1992) Influence of the pH-Value on the Growth of Staphylococcus epidermidis, Staphylococcus aureus and Propionibacterium acnes in Continuous Culture. Zentralblatt für Hygiene und Umweltmedizin, 193, 78-90.

[32] Gu, X.N., Zhou, W.R., Zheng, Y.F., Cheng, Y., Wei, S.C., Zhong, S.P., Xi, T.F. and Chen, L.J. (2010) Corrosion Fatigue Behaviors of Two Biomedical Mg alloys-AZ91D and WE43-In Simulated Body Fluid. Acta Biomaterialia, 6, 4605-4613. http://dx.doi.org/10.1016/j.actbio.2010.07.026

[33] Weckwerth, P.H., Zapata, R.O., Vivan, R.R., Tanomaru Filho, M., Maliza, A.G. and Duarte, M.A. (2013) In Vitro Alkaline pH Resistance of Enterococcus faecalis. Brazilian Dental Journal, 24, 474-476. http://dx.doi.org/10.1590/0103-6440201301731

[34] Yan, P.F., Liang, J.P. and Jiang, Y.T. (2012) The Influence of Different Alkaline pH Conditions on Enterococcus faecalis in Planktonic and Biofilm Mode. Shanghai Journal of Stomatology, 21, 6-8. 
Scientific Research Publishing (SCIRP) is one of the largest Open Access journal publishers. It is currently publishing more than 200 open access, online, peer-reviewed journals covering a wide range of academic disciplines. SCIRP serves the worldwide academic communities and contributes to the progress and application of science with its publication.

Other selected journals from SCIRP are listed as below. Submit your manuscript to us via either submit@scirp.org or Online Submission Portal.
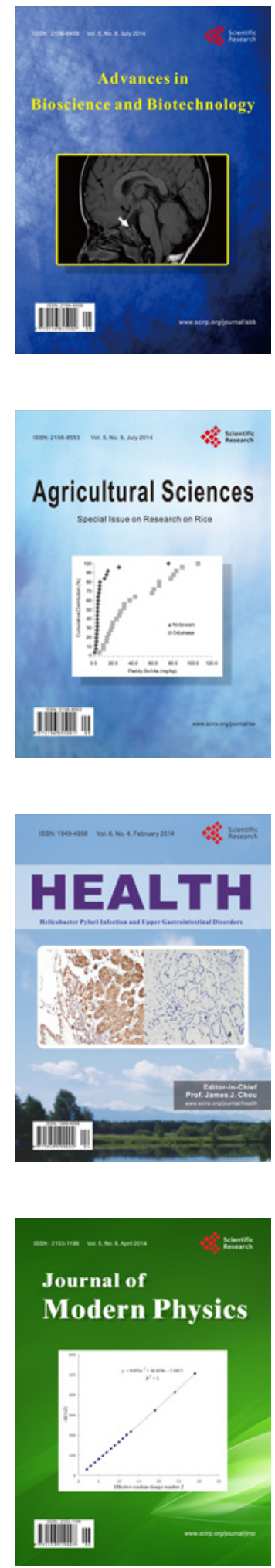
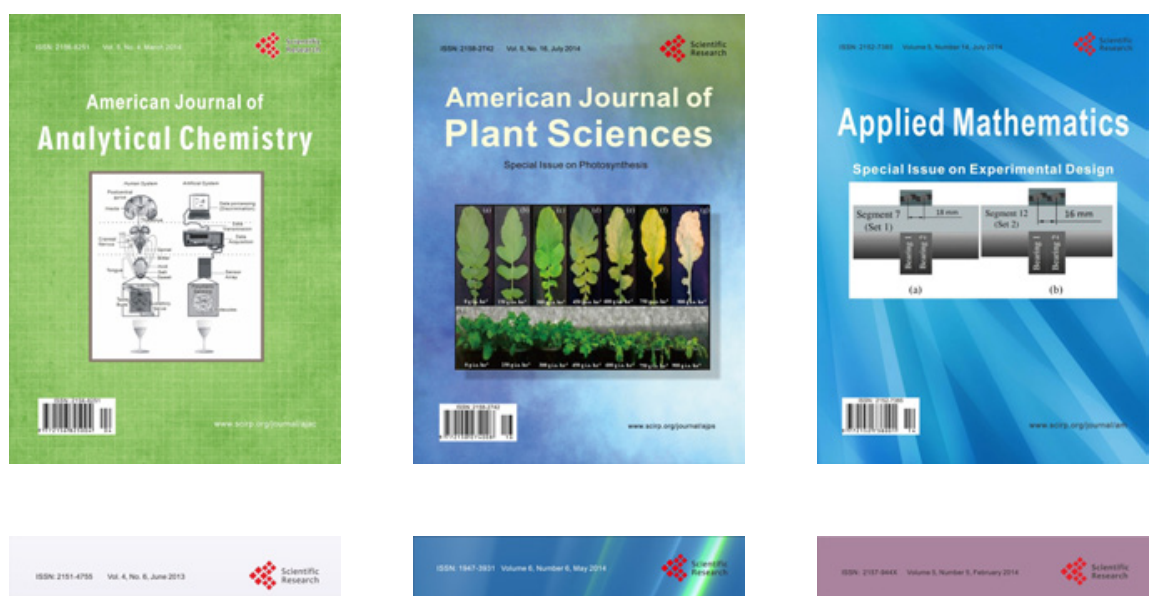

Creative Education
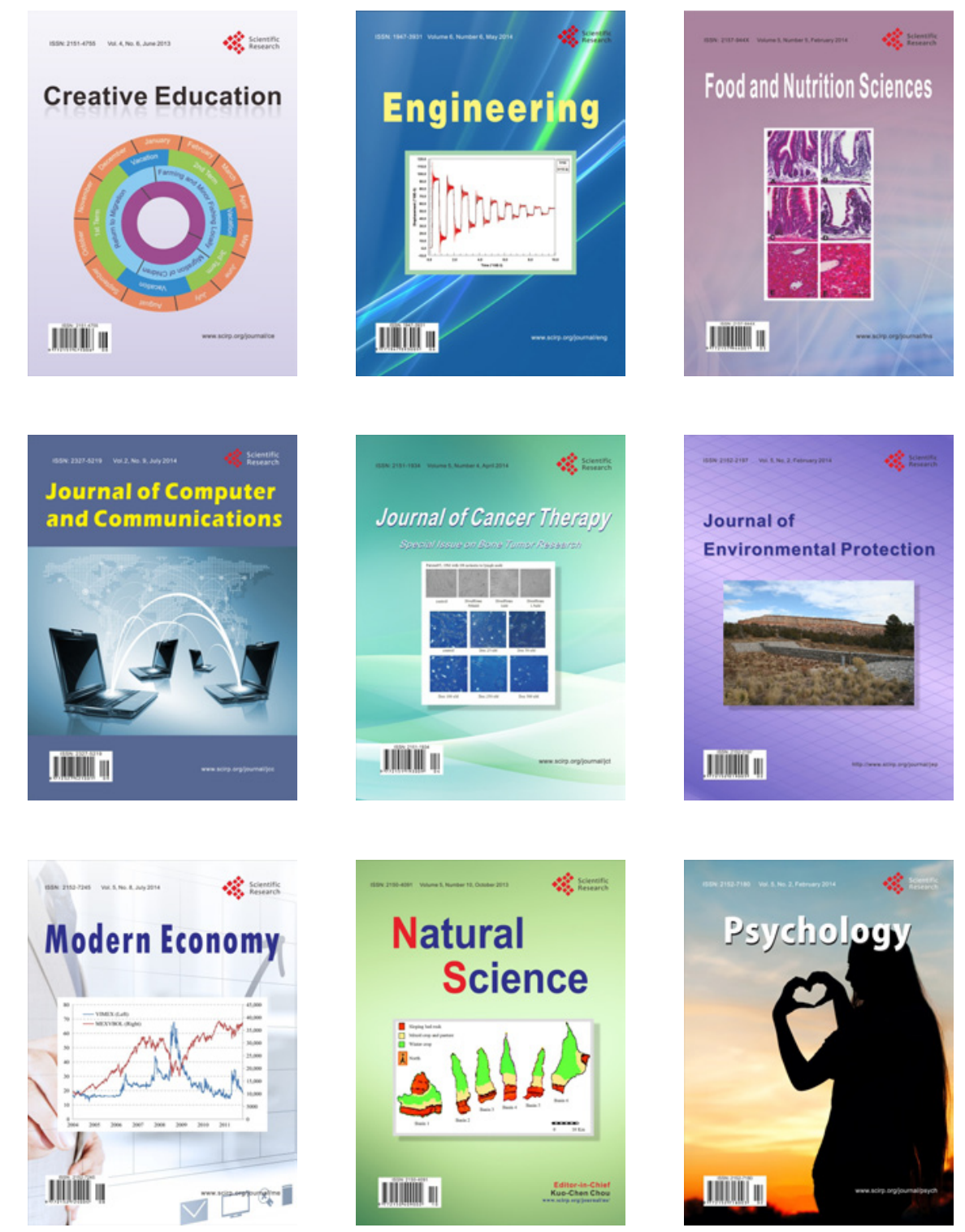